Natalia KLEJDYSZ

Poznań

\title{
Wiedźmy i dziwadła, czyli polska droga do parytetu
}

G dy przyjrzymy się dyskusji, jaka towarzyszyła wprowadzeniu parytetu do polskiej ordynacji wyborczej, możemy odnieść wrażenie, iż wielu przeciwnikom tego rozwiązania wciąż towarzyszą obawy wyrażone przez Sokratesa dwa i pół tys. lat temu: Zrównana w prawach z mężczyzna kobieta staje się natychmiast jego zwierzchnikiem. Wprawdzie już pod koniec średniowiecza pojawiły się pierwsze głosy kobiet w sprawie równouprawnienia, ale były to wypowiedzi nieliczne i mało znaczące ${ }^{1}$. W wieku XVI i XVII, gdy płoną stosy pod czarownicami, pod pseudonimem Jane Anger ukazuje się książka $W$ obronie kobiet, której autorka wnosi o równy dostęp kobiet i mężczyzn do wykształcenia, natomiast Maria de Jars de Gourney w swej Równości mężczyzn i kobiet zwraca uwagę na równe zdolności obu płci. Jednak do dopiero Oświecenie, a zwłaszcza rewolucja francuska, sprawiają, że głos kobiet staje się bardziej słyszalny. Tym samym wzbiera pierwsza fala feminizmu. Głos w dyskusji zabierają nie tylko kobiety. Rzecznikiem ich równouprawnienia staje się między innymi Antoine Nicolas Condorcet, pisząc pracę: Nadanie kobietom obywatelstwa.

W Stanach Zjednoczonych i Wielkiej Brytanii od połowy XIX wieku sufrażystki żądają równego prawa do głosowania. W Polsce ruch ten nie zyskał zbyt dużego poparcia nie dlatego, że Polkom nie zależało na prawach wyborczych, lecz zaważyła na tym szczególna sytuacja polityczna. Jest to przecież okres zaborów i to właśnie odzyskanie niepodległości absorbuje polskie aktywistki. Z drugiej strony- potencjalne represje ze strony zaborców powstrzymują Polki przed powoływaniem organizacji wypowiadających się w imieniu kobiet. Dlatego też specyficznym rysem polskiego feminizmu w tym okresie jest indywidualna działalność aktywistek, np. Klementyny Hoffmanowej, czy też redaktorki kobiecego pisma „Bluszcz”, Marii Ilnickiej. W latach 1850-1860 szczególną rolę odegrały tzw. Entuzjastki. Była to grupa warszawskich inteligentek, na czele których stała Narcyza Żmichowska, domagających się wszechstronnej emancypacji kobiet. Wśród propagatorek feminizmu na przełomie wieków wyróżniały się również: Anna Dobrska, Maria Wysłouchowa czy Kazimiera Bujwidow.

Prawa wyborcze Polki zyskały (a raczej wywalczyły) na mocy dekretu Józefa Piłsudskiego z 28 listopada 1918 roku $^{2}$. Jednak, jak się wkrótce okazało, w rzeczywistości mogły korzystać jedynie z czynnego prawa wyborczego, ponieważ na listach wyborczych raczej nie umieszczano kobiet. Przywódcy partii politycznych niechętnie, a nawet wrogo, odnosili się do takich pomysłów. Roman Dmowski, zwracając się do Izabeli Lutosławskiej, inicjatorki Narodowej Organizacji Kobiet, która na ten problem zwróciła mu uwagę, stwierdził: Stuchaj Belu, zaczynasz się wykolejać! Dotąd bytaś normalna dziewczyna i niewiele miatem ci do za-

\footnotetext{
${ }^{1}$ Np. Ch. de Pizan, Ksiażka miasta kobiet, 1405.

${ }^{2}$ Dekretem tym J. Piłsudski wprowadził równe prawa wyborcze dla wszystkich obywateli: kobiet i mężczyzn. Znalazło to potwierdzenie w zapisie Konstytucji marcowej z 1921 roku. Na mocy dekretu z 1918 roku Polki uzyskały również równy dostęp do edukacji na wszystkich poziomach i kierunkach, równe prawo do pracy i zrzeszania się.
} 
rzucenia, ale jak mi się zaczniesz mieszać do polityki, to będziesz dziwadtem, wiedźma i nie wyjdziesz nigdy za maż! - A ja też potrafię wymówić ci przyjaźń, bo brzydzę się szarlataneria kobieca. Wszystko blaga, próżność i pozory ${ }^{3}$.

Pierwszą kobietą w polskim parlamencie była działaczka Ligii Obrony Praw Człowieka i Obywatela, Irena Kosmowska, która zasiadała w Sejmie w latach 1919- 1930 z ramienia PSL Wyzwolenie. Była ona również pierwszą kobietą w rządzie, piastując stanowisko wiceministra opieki społecznej ${ }^{4}$.

Liczba kobiet zasiadająca w międzywojniu w ławach poselskich i senatorskich nie była imponująca. W ciągu dwudziestu lat wolnej Polski piastowały 41 mandatów poselskich i 20 senatorskich, co stanowiło odpowiednio ok. 2 i 4 proc. wszystkich posłów i senatorów ${ }^{5}$.

Przyjmując w 1918 roku zmiany w prawie wyborczym, Polska uplasowała się w pierwszej czwórce europejskich państw-pionierów w tej sferze ${ }^{6}$ : w 1906 r. kobiety uzyskały prawo głosu w Finlandii, w 1913 - w Norwegii, w 1915 - w Danii, a w 1918 - w Belgii, Irlandii, Wielkiej Brytanii i właśnie w Polsce.

Podobnie jak I wojna światowa, również działania wojenne w latach 1939-1945, paradoksalnie, przyczyniły się wzmocnienia pozycji kobiet. Oto udowodniły one swą przydatność i umiejętności również w sferach, które formalnie lub zwyczajowo były zarezerwowane dla mężczyzn. Jednak w krajach bloku wschodniego, w tym w Polsce, mamy do czynienia ze specyficzną sytuacją. Brak wolnych wyborów i fasadowość polskiego Sejmu podporządkowanego rządzącej PZPR, wszystko to powoduje, że dziś trudno ocenić rzeczywiste zaangażowanie i uczestnictwo kobiet w polityce. Umieszczane na listach kandydatów kobiety miały jedynie być świadectwem, iż skład polskiego parlamentu faktycznie odzwierciedla strukturę polskiego społeczeństwa. Przez cały okras istnienia PRL kobiety w Sejmie stanowiły maksymalnie 23 proc. $^{7}$, a w Biurze Politycznym KC PZPR pierwsza kobieta pojawiła się dopiero w 1981 roku. Była to Zofia Grzyb, brygadzistka z Radoskóru.

Druga fala feminizmu, która narodziła się w Stanach Zjednoczonych, ale wpłynęła również na świadomość Europejek pod koniec lat 60 . i na początku 70., nie była zauważalna w Polsce. Na świecie powstawały organizacje i stowarzyszenia kobiece, walczące z dyskryminacją zawodową i społeczną oraz o rzeczywiste równouprawnienie płci, a w Polsce władze zezwoliły na działalność Ligii Kobiet Polskich oraz Kół Gospodyń Wiejskich.

Transformacja ustrojowa zapoczątkowana w 1989 roku nie przyniosła zasadniczej zmiany. W tym samym roku odbyły się pierwsze, częściowo demokratyczne, wybory do dwu izb parlamentu: Sejmu i Senatu. Na 2500 kandydujących osób, kobiet było zaledwie 200. Do Sejmu kontraktowego weszły 62 kobiety, a do Senatu - 7, co stanowiło odpowiednio 13,5 oraz 7 proc. składu ${ }^{8}$. Kandydatki reprezentujące NSZZ „Solidarność” posiadały rekomendację

\footnotetext{
${ }^{3}$ Cyt. za: E. Lisowska, Równouprawnienie kobiet i mężczyzn w społeczeństwie, Warszawa 2008, s. 211.

${ }^{4}$ Mowa tutaj o Rządzie Tymczasowym powołanym przez Ignacego Daszyńskiego. Patrz: M. Fuszara, Udział kobiet we władzy, http://temida.free.ngo.pl.

${ }^{5}$ E. Lisowska, op. cit.

${ }^{6}$ W 1893 roku prawa wyborcze uzyskały kobiety w Nowej Zelandii, w 1902-w Australii, a w 1918 - w Kanadzie. Zatem nawet w skali światowej osiągnięcie Polek jest imponujące.

${ }^{7}$ W 1956 roku było to 6 procent. Patrz: R. Siemieńska, Wybierane i głosujace. Kobiety w wyborach parlamentarnych III Rzeczpospolitej, w: Kobiety: dawne i nowe role, „Biuletyn Centrum Europejskiego Uniwersytetu Warszawskiego i Ośrodka Informacji i Dokumentacji Rady Europy” 1994, nr 1, s. 27. Natomiast M. Fuszara pisze o 4 procentach kobiet w Sejmie w latach 1956-1961. Patrz: M. Fuszara, op. cit., s. 24. Wspomniane 23 proc. składu Parlamentu kobiety stanowiły w Sejmie VIII kadencji w latach 1980-1985. Ibidem.

${ }^{8}$ R. Siemieńska, op. cit., s. 28.
} 
Lecha Wałęsy, w przypadku innych ugrupowań rekomendacji najczęściej udzielała Liga Kobiet Polskich czy Koła Gospodyń Wiejskich, czyli jedyne, istniejące przed 1989 rokiem, organizacje kobiece, a także istniejące partie polityczne i związki zawodowe. Wyjątek stanowiły kobiety ubiegające się o miejsce w Parlamencie bez rekomendacji, z własnej inicjatywy ${ }^{9}$.

W pierwszych prawdziwie demokratycznych wyborach do Parlamentu, w 1991 roku, liczba kandydatek była jeszcze mniejsza niż dwa lata wcześniej. Ostatecznie mandat posła uzyskały 44 z nich, a senatora - 8. Zatem w Sejmie I kadencji III RP zasiadało 9,5 proc., a w Senacie - 8 proc. kobiet. Najwięcej posłanek zasiadało w ławach poselskich Unii Demokratycznej - 12 (przy 62 mandatach) i tutaj stanowią one również największy procent pośród wszystkich posłów z UD, ani jedna kobieta nie reprezentowała Kongresu Liberalno-Demokratycznego (37 mandatów), Polskiej Partii Przyjaciół Piwa (16 mandatów) ani Mniejszości Niemieckiej (7 mandatów) $)^{10}$.

W Sejmie II kadencji (1993-1997) liczba kobiet nieznacznie wzrosła. Stanowiły one 13 procent. Pod tym względem wyraźnie zdystansował pozostałe partie Sojusz Lewicy Demokratycznej, w którego ławach zasiadło 28 kobiet. Druga w kolejności Unia Demokratyczna miała tylko 16 posłanek. Również następna kadencja Sejmu należała do kobiet z SLD - 31 mandatów. Na drugim miejscu uplasowała się Akcja Wyborcza Solidarność z 20. mandatami dla kobiet. Sejm III kadencji, ogólnie rzecz ujmując, powtórzył wynik sprzed trzech lat - w izbie niższej zasiadało 13 procent kobiet.

Od wyborów w 2001 roku procentowy udział kobiet w Sejmie nie zmienia się - stanowią one 20,4 proc. wszystkich posłów. W Sejmie IV kadencji zwycięski blok SLD i Unii Pracy reprezentowało 55 kobiet. Pięć lat później prym wiodła Platforma Obywatelska - 33 kobiety w ławach poselskich. Obecnie, w Sejmie VI kadencji, w ławach poselskich zasiada najwięcej kobiet z PO - 48. Zaskakujący jest stosunkowo niski wynik Sojuszu. Tylko 11 kobiet w parlamencie III RP posiada legitymację tej partii, co tylko częściowo można tłumaczyć słabym wynikiem SLD w wyborach.

$\mathrm{Na}$ tle innych państw europejskich wyniki te nie wyglądają imponująco. Jeśli probierzem zaangażowania kobiet w życie publiczne miałby być ich udział w Parlamencie, to dane są wręcz niepokojące. Z dwudziestoprocentowym wskaźnikiem sytuujemy się na $14 .^{11}$ miejscu pośród krajów członkowskich Unii Europejskiej ${ }^{12}$. Pomijając, nieosiągalny na razie dla nas, wynik Andory czy państw skandynawskich ${ }^{13}$, znacznie więcej kobiet niż w polskim Sejmie zasiada np. w parlamencie holenderskim, hiszpańskim czy niemieckim, a nawet w Szwajcarii i Lichtensteinie, choć to tutaj kobiety jako ostatnie w Europie otrzymały prawa wyborcze ${ }^{14}$.

Jeśli weźmiemy pod uwagę ich udział w izbie wyższej, to wynik jest jeszcze gorszy - na 13 państw UE, gdzie takie izby istnieją, zajmujemy ostatnie miejsce (!).

\footnotetext{
${ }^{9}$ Ibidem.

${ }^{10}$ Ibidem, s. 32.

${ }^{11}$ Ex quo z Łotwa.

${ }^{12}$ Należy pamiętać, że w niektórych krajach nie ma wyższej izby parlamentu. A zatem 14. miejsce dotyczy udziału kobiet w izbie niższej oraz w parlamentach jednoizbowych.

${ }^{13}$ W Andorze kobiety stanowią 53,5 proc. w parlamencie, w Szwecji - 45 proc., w Finlandii - 42,5, w Danii-38, a w Norwegii - 39,6. Dane za: Inter-Parlimentary Union, Women in National Parliments, stan na 30 kwietnia 2011 roku, http://www.ipu.org/wmn-e/world.htm.

${ }^{14} \mathrm{~W}$ Lichtensteinie kobiety otrzymały równe mężczyznom prawo wyborcze w 1983 roku, w Szwajcarii - w roku 1971, ale ostatni kanton przyznał je kobietom dopiero w 1990 r.
} 
W Parlamencie Europejskim, biorąc pod uwagę liczbę kobiet w nim zasiadających, Polska sytuuje się na 23 (!) miejscu ${ }^{15}$. W ostatnich wyborach do Europarlamentu, które odbyły się w czerwcu 2009 roku, kobiety zdobyły 35 proc. mandatów w skali całej UE. Najwięcej kobiet jest wśród eurodeputowanych z Finlandii - 62 proc., około połowy zagwarantowanych dla danego kraju miejsc zdobyły również Szwedki i Estonki. Natomiast na pięćdziesięciu europosłów z Polski tylko 11 to kobiety, co stanowi 22 proc $^{16}$. Wybory w 2009 roku przyniosły niewielką poprawę w sferze reprezentatywności Europejek. W Parlamencie Europejskim poprzedniej kadencji kobiety stanowiły 31,4 proc. Polek - eurodeptowanych było zaledwie 14,8 proc. Na tle pięćdziesięcioprocentowych wyników Estonii, Luksemburga i Słowacji - wynik ten jest jeszcze mniej imponujący ${ }^{17}$.

W większości krajów, gdzie kobiety stanowią powyżej 30 proc. składu parlamentu, istnieją parytety. A zatem wprowadzenie tego typu rozwiązania również w Polsce jest szansą na zwiększenie udziału kobiet w życiu publicznym. Parytet bowiem ma być sposobem na walkę z ukrytą dyskryminacją. Polska, jako członek Organizacji Narodów Zjednoczonych, jest zobowiązana do przestrzegania ratyfikowanych przez nasz kraj dokumentów, które właśnie mają na celu walkę z wszelkimi przejawami dyskryminacji, w tym - ze względu na płeć.

Jednym z ważniejszych, ratyfikowanych jeszcze w okresie PRL, dokumentów jest Konwencja w sprawie likwidacji wszelkich form dyskryminacji kobiet, przyjęta przez Zgromadzenie Ogólne ONZ w 1979 roku $^{18}$. Artykuł 1 Konwencji zawiera definicję dyskryminacji kobiet. Jest to wszelkie, zróżnicowanie, wytaczenie lub ograniczenie ze względu na płeć, które powoduje lub ma na celu uszczuplenie albo uniemożliwienie kobietom, przyznania, realizacji badź korzystania na równi z mężczyznami z praw człowieka oraz podstawowych wolności $w$ dziedzinach życia politycznego, gospodarczego, społecznego, kulturalnego, obywatelskiego i in$n y c h^{19}$. Konwencja ta nakłada zatem na państwa strony obowiązek likwidacji wszelkich przejawów dyskryminacji ze względu na płeć, w tym dyskryminacji kobiet w życiu politycznym i publicznym. Traktuje o tym przede wszystkim art. 7. Państwo winno podjąć wszelkie kroki, by zapewnić kobietom na równych z mężczyznami warunkach prawo do: a) głosowania wyborach i referendach publicznych oraz kandydowania do wszelkich organów wybieranych powszechnie; b) uczestniczenia w ksztaltowaniu polityki państwa i jej realizacji, zajmowania stanowisk publicznych i wykonywania wszelkich funkcji publicznych na wszystkich szczeblach zarzadzania; c) uczestniczenia $w$ organizacjach pozarzadowych $i$ stowarzyszeniach zajmujacych się sprawami publicznymi i politycznymi Państwa ${ }^{20}$. Mowa więc nie tylko o zagwarantowaniu równości formalnoprawnej, ale również autentycznego wpływu na sferę publiczną i polityczną w związku z piastowanym stanowiskiem.

W 1982 roku powołano organ kontrolujący realizację postanowień Konwencji - Komitet ds. Likwidacji Dyskryminacji Kobiet (CEDAF), któremu państwa strony winny składać odpowiednie raporty. Sprawozdania te winny zawierać informację na temat działań podejmowanych w danym państwie na rzecz walki z dyskryminacją ze względu na płeć. Polska

\footnotetext{
15 Patrz: L. de Geringer Oedenberg, Parytet - czas na Polskę, 23.02.2010, w: Salon24.Niezależne forum publicystów, http://2009.salon24.pl.

${ }^{16}$ Obok Luksemburga, Czech i Włoch jest to jeden z najniższych odsetków. PAP, Parytety w Europie, http://info.wiara.pl, 18.02.2010.

${ }^{17}$ Dane z października 2008 r., za: Kobiety w Parlamencie Europejskim, http://www.bankier.pl, 1.06.2009, a także: Grupy polityczne i różnorodność w Parlamencie Europejskim, http://www.wybory2009.eu.

${ }^{18}$ Polska ratyfikowała Konwencję w 1980 roku z zastrzeżeniem odnośnie art. 29, § 1 (arbitraż międzynarodowy).

${ }^{19}$ Konwencja w sprawie likwidacji wszelkich form dyskryminacji kobiet, art. 1.

${ }^{20}$ Ibidem, art. 7.
} 
przedstawiała ostatnio taki raport Komitetowi w 2007 roku. Jednak już w latach 90. dostrzeżono, że system kontroli opierający się wyłącznie na sprawozdaniach przedkładanych przez państwa strony jest niewystarczający. Dlatego też w 1999 roku przyjęto protokół dodatkowy do Konwencji, na mocy którego osoby indywidualne lub organizacje mogą składać do Komitetu ds. Likwidacji Dyskryminacji Kobiet skargi na systematyczne łamanie praw kobiet w danym kraju ${ }^{21}$.

Komitet może również formułować rekomendacje, które dotyczą kwestii, na jakie państwa strony winny zwrócić większą uwagę. W rekomendacji z 1988 roku zalecono, w celu ograniczenia dyskryminacji, korzystanie ze środków specjalnych, takich jak akcje pozytywne, systemy kwotowe [podkr. - N. K.], traktowanie preferencyjne w celu zwiększenia udziatu kobiet w ekonomii, zatrudnieniu i polityce ${ }^{22}$. Zatem pożytek płynący z działań wyrównawczych pod postacią parytetów został już dostrzeżony na forum międzynarodowym 23 lata temu!

Niezwykle istotną rolę, z punktu widzenia walki z wszelkimi przejawami dyskryminacji kobiet, odegrały Światowe Konferencje na rzecz Kobiet, organizowane czterokrotnie pod auspicjami ONZ. Ostatnia, czwarta Konferencja odbyła się w Pekinie w 1995 roku $^{23}$. Piętnaście lat wcześniej w Nairobi rządy państw stron poczyniły zobowiązania dotyczące wprowadzenia w swoich krajach rozwiązań zmierzających do równouprawnienia kobiet i mężczyzn. W Pekinie delegacje poszczególnych państw miały zdać relacje z faktycznej realizacji tych zobowiązań. Jedną z płaszczyzn, której one dotyczyły było zwiększenie udziału kobiet w procesie podejmowania decyzji politycznych. Dokument końcowy Konferencji Pekińskiej wymienia 12 obszarów kluczowych z punktu widzenia ograniczenia dyskryminacji kobiet. Jednym z nich jest obszar: Kobiety a władza i proces decyzyjny ${ }^{24}$. Dokument końcowy Konferencji wskazywał konieczność przeanalizowania i być może weryfikacji przez rządy państw systemów wyborczych pod kątem zwiększenia faktycznej wybieralności kobiet do parlamentów. Podkreślono również konieczność stworzenia w ramach struktur rządów narodowych specjalnej instytucji, która byłaby odpowiedzialna za likwidację dyskryminacji, jak również monitorowanie wypełniania zaleceń Platformy działania ${ }^{25}$.

W czerwcu 2000 roku w Nowym Jorku odbyła się 23 sesja Zgromadzenia Ogólnego ONZ pod tytułem „Kobiety 2000: równość płci, rozwój i pokój na XXI wiek”, zwana również „Pekin +5 ". Poddano ocenie poziom realizacji w poszczególnych państwach wskazań pekińskiej Platformy działania.

„Pekin po dziesięciu latach - przegląd i ocena” - pod tym hasłem, w rocznicę Konferencji pekińskiej, odbyła się 49. sesja Komitetu ds. Statusu Kobiet. Przyjęto wówczas deklarację utrzymania zobowiązań podjętych dziesięć lat wcześniej, ponieważ, mimo dostrzegalnego postępu w likwidacji dyskryminacji kobiet, nadal istnieje problem z egzekucją równouprawnienia na wielu płaszczyznach.

$\mathrm{Na}$ gruncie europejskim rolę strażnika praw człowieka, demokracji i tolerancji pełni, utworzona w 1949 roku, Rada Europy. Polska jest jej członkiem od 1991 roku. W 1953 roku weszła w życie, wzorowana na Powszechnej Deklaracji Praw Człowieka ONZ, Konwencja o ochronie praw człowieka i podstawowych wolności. Jeśli prawa zagwarantowane Konwen-

\footnotetext{
${ }^{21}$ Protokół ten wszedł w życie w 2000 roku, a Polska ratyfikowała go trzy lata później.

${ }^{22}$ E. Lisowska, op. cit., s. 235. Na temat Konwencji, patrz: Kilka uwag o Konwencji w sprawie eliminacji wszelkich form dyskryminacji kobiet oraz Deklaracji o eliminacji przemocy wobec kobiet, Warszawa 2002.

${ }^{23}$ Poprzednie Konferencje: Meksyk 1975 rok, Kopenhaga 1980 r., Nairobi 1980 r.

${ }^{24}$ Czwarta Światowa Konferencja na rzecz Kobiet. Pekin 1995. Platforma działania, Warszawa 1995.

${ }^{25}$ Ibidem.
} 
cja są łamane, każdy ma prawo złożyć skargę do Europejskiego Trybunału Praw Człowieka w Strasburgu. W ramach Rady Europy działa, zajmujący się problemem równouprawnienia płci, Komitet Zarządzający ds., Równości Kobiet i Mężczyzn. Jest to instytucja odpowiedzialna za definiowanie, opiniowanie i stymulowanie działań Rady Europy na rzecz równości płci. Komitet prowadzi analizy, badania i przygotowuje konferencje ministrów oraz publikuje materiały $^{26}$. Bodźcem pobudzającym Komitet do aktywniejszej działalności w sferze walki z dyskryminacją była niewątpliwie Konferencja w Pekinie, choć już rok wcześniej można było dostrzec zmianę retoryki wypowiedzi w kwestii równouprawnienia.

$\mathrm{Na}$ gruncie Unii Europejskiej fundamentalne znaczenie dla podejmowanych działań koncentrujących się na walce o równouprawnienie płci mają traktaty: rzymski z roku 1958, z Maastricht z 1993 r., amsterdamski z 1997 roku. Traktat z Maastricht w ogólny sposób odwołuje się do obowiązku poszanowania praw człowieka, natomiast traktaty: rzymski i amsterdamski odnoszą się do dyskryminacji zawodowej kobiet i w tym zakresie formułują zalecenia.

Szczegółowe rozwiązania, dotyczące walki z dyskryminacją, zostały zawarte w dyrektywach, rozporządzeniach, zaleceniach i decyzjach. Ponadto, co cztery lata Unia opracowuje programy działania, w których wskazuje się konkretne sfery dyskryminacji i niedociąnnięcia rządów w realizacji zasady równouprawnienia. Spośród powstałych do tej pory programów, z punktu widzenia równouprawnienia kobiet i mężczyzn w polityce, na szczególną uwagę zasługuje program czwarty (1996-2000), w którym mowa m.in. o zwiększaniu wpływu kobiet na decyzje polityczne; a także program szósty, realizowany obecnie (2007-2012). W jednym z jego obszarów znajduje się postulat równego udziału kobiet i mężczyzn w gremiach decyzyjnych, zarówno w polityce, jak i biznesie ${ }^{27}$.

W strukturach UE istnieją również instytucje, których zadaniem jest monitorowanie i rozwiązywanie problemu dyskryminacji, choć ich działania koncentrują się na aktywności zawodowej, eliminacji działań dyskryminujących kobiety przez pracodawców lub współpracowników. Tak więc w ramach Komisji Europejskiej działa Wydział Równych Szans Kobiet i Mężczyzn, wspomagający Grupę Ekspertów ds. Równouprawnienia Kobiet i Mężczyzn, Komitet Konsultacyjny ds. Równego Statusu oraz inne pomniejsze komórki funkcjonujące w ramach różnych dyrekcji.

Przy Parlamencie Europejskim, jako ciało doradcze, funkcjonuje Komisja Praw Kobiet i Równych Szans, której zadaniem jest włączanie problematyki równouprawnienia do każdego obszaru polityki UE. Przy Dyrekcji Generalnej PE istnieje również Wydział ds. Praw Kobiet $^{28}$.

Rzeczywiste równouprawnienie kobiet i mężczyzn jest zatem przedmiotem troski zarówno ONZ, jak i Unii Europejskiej. Polska, jako członek obu organizacji, jest zobowiązana do respektowania zaleceń Organizacji Narodów Zjednoczonych oraz dostosowania prawa krajowego do wymogów UE. Podstawą prawną tychże zmian jest Konstytucja RP z 1997 roku. Artykuł 32 ustawy zasadniczej stanowi, iż wszyscy są równi wobec prawa i nikt nie może być dyskryminowany, z jakiejkolwiek przyczyny, zarówno w życiu publicznym, jak i społecznym czy gospodarczym. W kolejnym artykule Konstytucji została wyraźnie podkreślona równość kobiet i mężczyzn $w \dot{z} y c i u$ rodzinnym, politycznym, społecznym i gospodarczym ${ }^{29}$; mają

\footnotetext{
${ }^{26}$ E. Lisowska, op. cit., s. 241.

${ }^{27} \mathrm{http}$ ://ec.europa.eu.

${ }^{28}$ E. Lisowska, op. cit., s. 248.

${ }^{29}$ Konstytucja RP, art. 33, pkt 1.
} 
równe prawa m.in. do petnienia funkcji oraz uzyskiwania godności publicznych ${ }^{30}$. Uchwalenie Konstytucji poprzedziły konsultacje prezydenta Aleksandra Kwaśniewskiego z różnymi środowiskami społecznymi, w tym - z kobiecymi, z Centrum Praw Kobiet na czele. Jednak propozycje zmian w brzmieniu niektórych artykułów - nie zostały przyjęte.

Teoretycznie, nad respektowaniem równości praw kobiet i mężczyzn, na płaszczyźnie życia prywatnego, społecznego i publicznego, powinien czuwać specjalnie w tym celu powołany urząd. W Polsce po raz pierwszy utworzono taki urząd już w 1986 roku $^{31}$, a motywacji do takiej decyzji dostarczyły niewątpliwie ustalenia konferencji w Nairobi. Otrzymał on nazwę Urzędu ds. Kobiet i został umieszczony w strukturze Ministerstwa Pracy i Polityki Społecznej. Od tamtej pory urząd ten podlegał licznym zmianom. W formule ustalonej w 1986 roku przetrwał trzy lata. Ponownie powołano go w 1991 roku $^{32}$ pod nazwą: Urząd Pełnomocnika Rządu ds. Kobiet i Rodziny, a swą działalność zakończył w 1992 roku, po niespełna roku funkcjonowania. Decyzja ta tym bardziej zdumiewa, że rok 1992 był rokiem szczególnych osiągnięć kobiet: Hanna Suchocka zostaje premierem rządu, Hannę Gronkiewicz-Walz Sejm powołał na stanowisko prezesa NBP, powstaje Federacja Klubów Kobiet Aktywnych Zawodowo, a Małgorzata Fuszara i Eleonora Zielińska rozpoczynają prace nad pierwszym projektem ustawy o równym statusie kobiet i mężczyzn. Wakat na stanowisku pełnomocnika utrzymał się do 1994 roku, kiedy to, w wyniku wyborów, rządy przejęła koalicja SLD-PSL. Zapewne pod presją zbliżającej się konferencji ONZ ds. kobiet w Pekinie na stanowisko Pełnomocnika ds. Rodziny i Kobiet powołano Brabarę Blidę, która w tym czasie pełniła funkcję ministra budownictwa i sama twierdziła, że nie interesuje jej problematyka kobiet, a pełnienie urzędu Pełnomocnika traktuje jako „,balast” ${ }^{\text {33 }}$. Wraz ze zmianą na tym stanowisku, w 1995 roku zmieniono również po raz kolejny jego nazwę. Tym razem miał to być Pełnomocnik ds. Kobiet i Rodziny, a została nim Jolanta Banach. Po wyborach parlamentarnych w 1997 roku urząd zlikwidowano, powołując jednocześnie urząd Pełnomocnika Rządu ds. Rodziny, a funkcję tę powierzono Kazimierzowi Kaperze z ZCHN. Jego kontrowersyjne wypowiedzi na temat antykoncepcji czy homoseksualizmu zmusiły go w 1999 roku do dymisji, a urząd objęła Anna Smerczyńska, należąca, podobnie jak Kapera, do Polskiej Federacji Stowarzyszeń Rodzin Katolickich.

W roku 2001 na mocy rozporządzenia Rady Ministrów zostaje ustanowiony urząd Pełnomocnika Rządu ds. Równego Statusu Kobiet i Mężczyzn - zostaje nim Izabela Jaruga-Nowacka $^{34}$. Obecnie funkcję Pełnomocnika Rządu ds. Równego Traktowania pełni, niezbyt przychylnie postrzegana przez środowiska kobiece, Elżbieta Radziszewska. W czerwcu 2010 roku weszła w życie pierwsza nowelizacja rozporządzenia z dn. 22 kwietnia 2008 r. w sprawie Pełnomocnika Rządu do spraw Równego Traktowania ${ }^{35}$. Do dotychczasowych zadań dołączono m.in. kompetencje w zakresie nawiązywania współpracy z innymi państwami, organizacjami i instytucjami międzynarodowymi i zagranicznymi ${ }^{36}$.

\footnotetext{
${ }^{30}$ Ibidem, pkt 2.

${ }^{31}$ Pierwszą pełnomocniczką była Anna Kędzierska.

32 Tym razem pełnomocniczką została Anna Popowicz.

${ }^{33}$ U. Nowakowska, Instrumenty państwa na rzecz awansu kobiet, w: Kobiety w Polsce - w latach 90, http://www.webcache.googleusercontent.com, s. 2.

${ }^{34}$ Kalendarium - historia kobiet w Polsce, http://webcache.googleusercontent.com, 6.03.2011.

35 Dz. U. 2010, Nr 109, poz. 710.

${ }^{36}$ Patrz: Nowe kompetencje Petnomocnika Rzqdu do spraw Równego Traktowania, opr. A. Wójcik, w: Dyskryminacja płciowa, http://www.cpk.org.pl.
} 
W 1996 roku inicjatywę w sprawie projektu ustawy o równym statusie kobiet i mężczyzn przejmuje, powołana w 1990 roku, Parlamentarna Grupa Kobiet, skupiająca posłanki i senatorki z różnych partii, klubów poselskich i senatorskich. Mimo że strategia wyrównywania szans została zawarta w Platformie Pekińskiej, to ani w 1997 ani w 1999 roku projekty tej ustawy nie przeszły przez polski parlament. Również podjęta przez SLD w 2001 roku próba wprowadzenia do ordynacji wyborczej systemu kwotowego zakończyła się niepowodzeniem. Mimo to Sojusz Lewicy Demokratycznej, Unia Wolności i Unia Pracy zobowiązały się do kwot trzydziestoprocentowych na listach wyborczych kandydatów z własnych partii. Kandydatki otrzymały wsparcie ponadpartyjnej nowo powstałej Przedwyborczej Koalicji Kobiet. A w ramach UW, SLD, UP i PSL powstawały wewnętrzne porozumienia kobiet, których celem było wywieranie presji na kierownictwa partii przy układaniu list wyborczych. Efekt tych zabiegów stał się widoczny po podsumowaniu wyników wyborów. Udział kobiet w sejmie w 2001 roku wzrósł do 20 proc., a w senacie do 23 proc. $^{37}$

Okazało się jednak, że sukces ten jest krótkotrwały. Dwie kolejne kadencje parlamentu nie przyniosły wprawdzie zasadniczych zmian w udziale kobiet w izbie niższej, lecz w senacie w latach 2005-2007 zasiadało ich już tylko 13 proc, a obecnie jest to zaledwie 8 proc. Dla polskich środowisk kobiecych stało się jasne, że bez rozwiązań instytucjonalnych problem niskiego uczestnictwa Polek w życiu publicznym nie zostanie rozwiązany. Mając na potwierdzenie słuszności rozumowania wzorce w postaci rozwiązań parytetowych w innych krajach, a także zielone światło dla tego typu regulacji ze strony organizacji międzynarodowych, czy choćby pekińskiej Platformy Działania, zaczęto poważnie zastanawiać się nad możliwością wprowadzenia parytetu do polskiej ordynacji wyborczej. Poważna i konstruktywna dyskusja nad tym rozwiązaniem rozpoczęła się wraz z Kongresem Kobiet Polskich w czerwcu 2009 roku $^{38}$, kiedy to zapowiedziano przygotowanie projektu ustawy, zmieniającego ordynację wyborczą. Obywatelski projekt ustawy o parytecie został złożony u marszałka Sejmu, Bronisława Komorowskiego, w grudniu tegoż roku. Pod projektem podpisało się ponad 120 tys. osób i, co znamienne, tylko co czwarty podpis należał do mężczyzny ${ }^{39}$.

Proponowany przez Kongres parytet to 50/50. W przypadku nieparzystej liczby kandydatów na liście zaproponowano stepujące rozwiązanie: Liczba kobiet na liście [...] nie może być mniejsza niż liczba mężczyzn. A zatem, w takiej sytuacji, kobiet na liście powinno być więcej. W uzasadnieniu do projektu ustawy czytamy: Komitety wyborcze nie sq jednak zwiazane narzucona im z góry koniecznościa umieszczania na listach nieparzystej liczby kandydatów, moga więc zachować parytet $50 / 50^{40}$. Konsekwencją odejścia od zasady parytetu miała być odmowa rejestracji listy wyborczej przez odpowiednią komisję wyborczą. Komitet miał mieć jednak prawo do jej skorygowania, a także do odwołania się do komisji wyższego szczebla, nadzorującego przebieg wyborów.

Projekt ustawy nie przewidywał regulacji dotyczących kolejności kandydatów na listach wyborczych, a więc nie uwzględniono ,,podwójnego parytetu”. Projektodawcy wyrazili jednak nadzieję, że te partie, które nie tylko deklaruja gotowość realizacji zasady równości po

\footnotetext{
${ }^{37}$ Pod koniec kadencji było to odpowiednio: 21 i 24 proc.

${ }^{38} \mathrm{Nie}$ oznacza to, że problem parytetu nie pojawiał się już wcześniej w wypowiedziach polskich feministek. Jednakże dopiero od czerwca 2009 roku w dyskusję zaangażowały się różnorodne, nie tylko feministyczne, środowiska.

${ }^{39}$ Dane na podstawie wypowiedzi Kingi Dunin w: Parytet w Sejmie na razie tylko w podpisach, „Gazeta Wyborcza” z 22.12.2009, wyd. internetowe.

${ }^{40}$ Projekt ustawy o zmianie ustawy-Ordynacja wyborcza do Sejmu Rzeczypospolitej Polskiej i Senatu Rzeczypospolitej, ustawy - Ordynacja wyborcza do rad gmin, rad powiatów i sejmików województw oraz ustawy-Ordynacja wyborcza do Parlamentu Europejskiego, w zwiqzku z wprowadzeniem ptci na listach kandydatów.
} 
względem ptci, lecz rzeczywiście daża do zapewnienia równych szans w wyborach swoim kandydatom i kandydatkom, będa przyjmowaty dobrowolne zobowiqzanie do przestrzegania zasady, żeby na miejscach ,jedynkowych" na partyjnych listach wyborczych nie byto mniej kobiet niż mężczyzn ${ }^{41}$. Podkreślano również, że tego typu rozwiązania w żaden sposób nie uprzywilejowują kobiet, jednocześnie prowadząc do dyskryminacji mężczyzn. Parytet bowiem ma być drogą do faktycznej równości szans. Wyboru dokonują przecież wyborcy. Umieszczenie większej niż dotychczas liczby kobiet na listach wyborczych daje wybierającym szersze spektrum osobowości i poglądów. Dla kobiet - kandydatek parytet nie jest gwarancją, a jedynie możliwością bycia wybraną.

Już w momencie otrzymania projektu ustawy ówczesny marszałek Sejmu, Bronisław Komorowski, zapowiedział przeprowadzenie debaty na temat parytetu $W$ tym wypadku marszałek musi skierować ten projekt, jako obywatelski, jak najszybciej pod obrady. Sadzę, że w lutym będziemy mieć duża, ogólnonarodowq debatę, na temat tego, co można zrobić najlepszego, aby zwiększyć aktywność politycznq i społeczna kobiet ${ }^{42}$, choć on sam nie był przekonany do tego rozwiązania. Parytety bowiem, jego zdaniem, spoglądając na przykłady państw, gdzie są one faktem, nie gwarantują wzrostu aktywności politycznej i społecznej kobiet ${ }^{43}$. Ponadto wyraził on obawę, że, podobnie jak we Francji w 1982 roku, parytet może okazać się niezgodny z Konstytucją ${ }^{44}$. Natomiast determinacja autorów i zwolenników zmian w ordynacji, była spowodowana nadzieją na przeprowadzenie najbliższych wyborów, wyborów samorządowych, w oparciu o nowe przepisy prawa ${ }^{45}$.

18 lutego 2010 roku w Sejmie odbyło się pierwsze czytanie obywatelskiego projektu o parytetach. Jasne stało się, że nadzieje projektodawców na wprowadzenie zmian w ordynacji już przed wyborami samorządowymi były bezpodstawne. Projekt ten bowiem cieszył się pełnym poparciem jedynie ze strony lewicy. A ta również miała pewne wątpliwości, jednak nie odnośnie treści, a sensu forsowania projektu, który nie ma szans na uchwalenie. Dlatego pojawiły się w SLD propozycje złagodzenia zmian proponowanych w projekcie - wprowadzenie czterdziestoprocentowego udziału kobiet na listach ${ }^{46}$. To „,nowe” rozwiązanie byłoby jednak ,starym” pomysłem Platformy Obywatelskiej. Platforma natomiast sama zrezygnowała wówczas z forsowania swojej propozycji odnośnie parytetów.

Po siedmiu miesiącach od pierwszego czytania obywatelskiego projektu ustawy w sprawie podziału miejsc na listach wyborczych między kobiety i mężczyzn, gdy projektem zajmowała się sejmowa podkomisja, przed siedzibą parlamentu zorganizowano demonstrację, której celem było przyspieszenie prac nad tym projektem oraz zakończenie ustawodawczych procedur. Henryka Bochniarz odniosła się wówczas do zaproponowanej poprawki, która mówiła o trzydziestopięcioprocentowej kwocie, zamiast pięćdziesięcioprocentowego parytetu. $\mathrm{Pa}$ trzymy na to z obrzydzeniem - stwierdziła, ale lepsze to niż nic ${ }^{47}$. Uczestniczki demonstracji obawiały się, że zgoda na to rozwiązanie zahamuje w rzeczywistości wprowadzenie parytetu.

Wybory samorządowe odbyły się zatem na dotychczasowych zasadach. Jednak, mimo to, można było dostrzec pewne zmiany w podejściu do zagadnienia poszczególnych komitetów

\footnotetext{
${ }^{41}$ Ibidem.

${ }^{42}$ Komorowski: Debata na temat parytetów w lutym, PAP, 21.12.2009, wyd. internetowe.

43 Odwołując się do przykładów Francji i Szwajcarii, pomija te kraje, gdzie parytet faktycznie „zadziałał”.

44 J. Cieśla, Trudne równanie, op. cit.

${ }^{45}$ Komorowski: Debata, op. cit.

${ }^{46}$ W Sejmie ważq się losy parytetu, http://news.mopney.pl, 18.02.2010.

${ }^{47}$ Kongres Kobiet upomina się o parytety, PAP, http://www.deon.pl.
} 
wyborczych: [...] starano się przynajmniej nie pomijać zupetnie kobiet wśród osób kandydujacych, a kobiety częściej walczyty o wysokie miejsca i nie dawaty się zepchnać na dalsze pozycje, co udawało im się często też dzięki zmianie dyskursu dotyczqcego udziatu kobiet w polityce $e^{48}$. Dzięki temu w wyborach do samorządu kobiety zdobyły 24 proc. miejsc w organach stanowiących, gdy cztery lata wcześniej było to 20,6 proc. Zadowalający jest również rezultat wyborów do rad małych miast i gmin, gdzie kobiety zajęły 26 proc. stanowisk, o które się starały, w miastach powyżej 20 tys. mieszkańców - 21,6 proc, a w dużych miastach blisko 24 proc. Najlepiej poradzity sobie w wyborach do rad dzielnic Warszawy - 37 proc. spośród nowych radnych to kobiety. W sejmikach wojewódzkich kobiety zajma 22,6 poc. miejsc, a w radach powiatów 17,7 proc. Jednak tylko 8 proc. nowych wójtów, 9 proc. nowych burmistrzów i 5,7 proc. nowych prezydentów miast to panie 49 .

W grudniu 2010 roku Sejm przyjął ustawę parytetową, wprowadzającą trzydziestopięcioprocentowy system kwotowy w wyborach samorządowych, parlamentarnych i w eurowyborach. Oznacza to, że nie mniej niż 35 proc. kobiet i nie mniej niż 35 proc. mężczyzn musi znaleźć się na listach wyborczych, aby te zostały zarejestrowane. W przypadku zgłoszenia listy zawierającej trzech kandydatów wśród nich musi znaleźć się co najmniej jedna kobieta lub co najmniej jeden mężczyzna. Zmiany dotyczą ordynacji wyborczej do rad gmin i powiatów, sejmików województw, Sejmu oraz do Parlamentu Europejskiego. Jednak w przypadku wyborów przedterminowych lub uzupełniających do organów stanowiących jednostek samorządu terytorialnego, przeprowadzanych w trakcie trwania kadencji, w czasie której ustawa ta weszła w życie, będą obowiązywały dotychczasowe zasady ${ }^{50}$. Ustawa nie obejmuje również wyborów do Senatu i do rad gmin o liczbie mieszkańców nie przekraczającej 20 tys., czyli tam, gdzie obowiązuje ordynacja większościowa ${ }^{51}$.

W przypadku, gdy, po zarejestrowaniu listy, kandydat lub kandydatka wycofa się, to naruszy zasadę 35 procent, lista taka nie traci na ważności. Sejm natomiast odrzucił poprawki nakazujące, by na trzech pierwszych miejscach znalazła się co najmniej jedna kobieta, a w pierwszej piątce minimum dwie kandydatki. W głosowaniu wzięło udział 404 posłów, z tego za przyjęciem ustawy było 241, przeciw - 154, a wstrzymało się od głosu - 9. Mimo że partie koalicji PO i PSL wprowadziły dyscyplinę w głosowaniu, to jednak kilkunastu posłów jej się nie podporządkowało. Wśród nich znalazł się poseł Jarosław Gowin, który, tłumacząc przyczyny swej niesubordynacji, stwierdził: Jestem z fundamentalnych względów przeciwny inżynierii społecznej. Kwoty ograniczaja wolność jednostki $i^{52}$.

Podpisując tę ustawę, prezydent Bronisław Komorowski wprowadził Polskę do grona 45. państw na świecie, gdzie odgórnie, w konstytucji lub ustawie, zostały określone zasady uczestnictwa kobiet w polityce. Drugie tyle - to państwa, gdzie pozostawiono decyzję partiom, które zobowiązują się do zapewnienia zarówno kobietom jak i mężczyznom odpowiedniej liczby miejsc na listach. Wśród krajów Unii Europejskiej odgórne regulacje istnieją we Francji, Belgii, Portugalii, Słowenii i Hiszpanii, a teraz - również w naszym kraju.

\footnotetext{
${ }^{48}$ M. Fuszara, Przegłosowanie kwot to największy sukces polityczny od 1918 roku, http://www.stowarzyszeniekongreskobiet.pl.

49 A. Pezda, Kobiety w samorzqdzie, http://wwwglosujteraz.pl.

${ }^{50}$ Ustawa z dnia 5 stycznia 2011 r. o zmianie ustawy-Ordynacja wyborcza do rad gmin, rad powiatówi sejmików województw, ustawy - Ordynacja wyborcza do Sejmu Rzeczypospolitej Polskiej i do Senatu Rzeczypospolitej Polskiej oraz ustawy - Ordynacja wyborcza do Parlamentu Europejskiego.

${ }^{51}$ Zamiast Parytetu - 35\% miejsc dla kobiet, PAP, http://www.deon.pl.

52 Cyt. za: M. Fuszara, Przegłosowanie kwot, op. cit., s. 2.
} 
Najbliższe wybory parlamentarne będą zarówno dla zwolenników, jak i przeciwników „ustawy parytetowej” ważnym sprawdzianem. Sukces kobiet może być bowiem odczytywany na dwa sposoby: zwolennicy parytetów zapewne stwierdzą, że wystarczył prosty system kwotowy, aby kobiety mogły liczniej zaistnieć na scenie politycznej, a dotychczasowe, słabsze wyniki kobiet w wyborach były skutkiem maskulinizacji systemu; natomiast przeciwnicy prawdopodobnie skonstatują, że stało się tak, ponieważ wyborcom nie pozostawiono alternatywy. Jeśli jednak udział kobiet w parlamencie RP, nie wzrośnie dzięki tym zmianom, zwolennicy parytetu będą przyczyny dopatrywać się w zbyt niskiej kwocie lub w braku sytemu suwakowego, a więc w usytuowaniu kobiet na listach. Przeciwnicy w słabych wynikach kandydatek będą widzieli potwierdzenie swojej tezy, iż dla wyborców istotne są kompetencje, a nie płeć i żadne odgórnie narzucone, naruszające Konstytucję rozwiązania tego nie zmienią.

Pewne jest, że za kilka miesięcy uzyskamy odpowiedź na pytanie: czy system kwotowy zadziałał? Ale możemy mieć pewność również, że wprowadzone zmiany będą przez środowiska kobiece, bez względu na wyniki wyborów, traktowane jako pierwszy krok w stronę autentycznej równości w polityce. My będziemy $w$ tej sprawie brać przykład z Belgii, gdzie najpierw wprowadzono kwoty, następnie naprzemienność na 2 pierwszych miejscach na liście, a następnie i parytet (50\%) i naprzemienność na pierwszych miejscach ${ }^{53}$.

Idąc niejako ,za ciosem” 7 marca 2011 roku Kongres Kobiet powołał Gabinet cieni, którego zadaniem będzie doradzanie politykom oraz komentowanie bieżących wydarzeń. Na czele Gabinetu stanęła europosłanka Danuta Hübner, która stwierdziła, Nie jesteśmy opozycja, jesteśmy konstruktywna propozycja. Myślimy o polityce bardzo poważnie ${ }^{54}$. W skład gabinetu weszły przedstawicielki Rady Programowej Kongresu Kobiet. Odnosząc się do swych propozycji personalnych, podkreśliły, że nie wszystkie resorty pokrywają się z tymi, które istnieją w rządzie obecnie: Ministerstwo Świeckości Państwa i Wielokulturowości, Ministerstwo ds. Równości Płci i Przeciwdziałania Dyskryminacji, Ministerstwo Energii, Środowiska i Rolnictwa oraz Ministerstwo Rozwoju Regionalnego i Spraw Wewnętrznych ${ }^{55}$. Ogłoszenie na konferencji prasowej składu Gabinetu cieni wywołało duże zainteresowanie mediów. Zastanawiające jest jednak to, że dziennikarze przede wszystkim koncentrowali się na kompetencjach szefowych poszczególnych Ministerstw. Chyba kwalifikacje żadnego z ministrów w rządach III RP nie wzbudziły takich wątpliwości, a tym bardziej Gabinetu cieni.

Działania na rzecz parytetu w polityce, które zakończyły się połowicznym sukcesem, będą zapewne kontynuowane i rozszerzane. Być może równolegle $\mathrm{z}$ tą inicjatywą zostaną podjęte starania o wprowadzenie parytetu płci lub systemu kwotowego w innych dziedzinach: w zarządach firm, czy też w szkolnictwie wyższym. Jeśli udział kobiet w politycznych gremiach decyzyjnych wzrośnie, pojawi się szansa na wprowadzenie rozwiązań ograniczających dyskryminację kobiet w sferze zawodowej czy społecznej.

\footnotetext{
${ }^{53}$ Ibidem, s. 3.

${ }^{54}$ Gabinet cieni Kongresu Kobiet. Premierem Huebner, MSZ dla Kwaśniewskiej, edukacja dla Środy, PAP, http://www.polskatimes.pl.

55 Skład Gabinetu cieni jest następujący: premier - Danuta Hübner, wicepremier i minister rozwoju przedsiębiorczości i innowacyjności - Henryka Bochniarz, wicepremier i minister rozwoju regionalnego i spraw wewnętrznych - Teresa Kamińska, minister ds. równości płci i przeciwdziałania dyskryminacji-Małgorzata Fuszara, minister spraw zagranicznych - Jolanta Kwaśniewska, minister edukacji, nauki i sportu - Magdalena Środa, minister energii, środowiska i rolnictwa - Lena Kolarska-Bobińska, minister pracy i spraw socjalnych - Henryka Krzywonos, Wanda Nowicka - minister zdrowia, Maria Pasło-Wisniewska - minister finansów, Eleonora Zielińska - minister sprawiedliwości, Kazimiera Szczuka - minister kultury, Barbara Labuda - minister świeckości państwa i wielokulturowości, Danuta Waniek - minister obrony, Beata Stelmach - minister skarbu, Solange Olszewska - minister infrastruktury, rzeczniczka - Dorota Warakomska. Źródło: ibidem.
} 


\section{Summary}

\section{Witches and Weirdos, or the Polish Road to Parity}

The next parliamentary elections in Poland will be held on the basis of the amended electoral law. The changes introduced involve a quota system: the ballots are required to provide for at least $35 \%$ of women and at least $35 \%$ of men. Nearly a hundred years passed from 1918 , when Polish women first won voting rights, till the President of Poland signed the so-called parity law. It would not be true, however, to say that this was a century of struggle for the equality of rights of men and women in our country. It was only after 1989 that efficient steps could be taken in this area in Poland. Therefore, the quota system that has been introduced, to be tested in practice soon, is actually the consequence of twenty years of endeavors. The advocates of such a solution consider this to be the first step towards electoral parity.

Following the solutions that numerous European countries have introduced, public debate in Poland increasingly more often refers to proposals to 'spread' the quota system, and then parity, also to other domains, such as management or education. The opening of a serious debate on these issues will to a large extent depend on the results of the recent quota changes of the electoral law. 